\section{ECONOMICS}

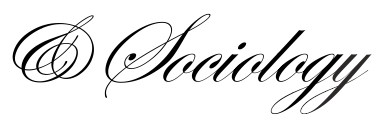

Dheera-aumpon, S., \& Changwatchai, P. (2020). Cultural distance and foreign direct investment stock in Thailand: Evidence from panel data. Economics and Sociology, 13(4), 81-96. doi:10.14254/2071-789X.2020/13-4/5

\title{
CULTURAL DISTANCE AND FOREIGN DIRECT INVESTMENT STOCK IN THAILAND: EVIDENCE FROM PANEL DATA
}

\author{
Siwapong Dheera-aumpon \\ Department of Economics, \\ Kasetsart University, \\ Bangkok, Thailand \\ E-mail: fecospd@a,ku.ac.th \\ ORCID 0000-0002-1840-6485 \\ Corresponding Author
}

Piyaphan Changwatchai

Department of Economics,

Kasetsart University,

Bangkok, Thailand

E-mail: fecoppc@,ku.ac.th

Received: December, 2019

1st Revision: March, 2020

Accepted: November, 2020

DOI: $10.14254 / 2071-$

789X.2021/13-4/5

JEL Classification: F2, M2, Z1

\begin{abstract}
Cultural distance can be defined as differences in cultural values and communication styles between the source and the host countries that can have negative impacts on stocks of FDI in the latter. Prior studies focused on the perspective of a source country and pooled data from various host countries but here we focus on the perspective of a host country and use data from a single host country, Thailand. To study the effect of cultural distance, data on 2006-2019 FDI stocks held in Thailand by foreign entities from 32 major source countries are collected. Results of a random effects regression model indicate that cultural distance between Thailand and a source country does not reduce but raises the stock of FDI. We conclude that culture in Thailand does not hinder the operations of foreign companies but instead enhances investment opportunities. In promoting FDI in Thailand, the government should aim at culturally distant source countries. In doing so, the government should emphasize that Thai culture is collective, feminine, and has high uncertainty avoidance.
\end{abstract}

Keywords: culture, collectivism, femininity, masculinity, uncertainty avoidance, FDI, Thailand.

\section{Introduction}

Foreign direct investment (FDI) as a specific type of inward investment that has been increasing in many developing countries, including Thailand, affecting several aspects of economy including employment, technology transfer, production efficiency and competitiveness (Su, Nguyen, \& Christophe, 2019; Vasa, \& Angeloska, 2020). Kohpaiboon (2006) found that FDI increased the productivity of manufacturing industries in Thailand. Conversely, Ananchotikul (2008) suggested that FDI either increased, or decreased corporate governance of Thai firms, while Yusoff and Nuh (2015) stated that FDI promoted economic growth of the country.

The stock of FDI in Thailand increased until 2015 and then the growth rate fluctuated. This attracted the attention of the researchers studying FDI and its determinants. Most of the studies on FDI in Thailand focused on variables determined from the gravity equation. It states that FDI between two counties is proportional to the sizes of their GDPs and inversely 
proportional to their geographical distance. To the best of our knowledge, none of the studies on FDI in Thailand has considered cultural variables.

Analyzing the factors affecting the stock of FDI, including cultural distances, is very important. Previous studies indicated that cultural distances or cultural differences in shared values and communication styles between the home and the host countries can have significant impacts on the stocks of FDI in host countries. In their pioneering work, Kogut and Singh (1988) concluded that cultural distances can affect the choice of entry modes, while Blonigen and Piger (2014) found that besides gravity variables, cultural variables had the most important effect on FDI.

Cultural differences are challenging and crucial to consider for an internationally expanding firm according to Gomez-Mejia and Palich (1997). Nayak and Scheib (2020) argued that differences due to culture included working styles, incentives, and consumer behavior can either promote, or damage a country's FDI attractiveness.

International business operations require interaction across borders. Constanza (2001) argued that the differences in culture might increase misunderstanding and jeopardize business success, and eventually could make FDI attempts unprofitable. Also, Hakanson and Ambos (2010) stated that differences in culture are prone to increase information requirements and search costs. Differences in culture, thereby, increase the costs of doing business.

Firms often prefer to invest in a country with similar culture rather than in a country with diverse culture and ethnicity. It is easier to understand markets, consumers, and business practices in a country that has a similar culture, and this promotes business operations. Tahir and Larimo (2004) argued that investors prefer to allocate their assets in culturally close countries rather than in culturally distant countries. Kandogan (2016) suggested that cultural differences might negatively affect stocks of FDI in host countries.

Differences in national culture between home and host countries affect FDI in various aspects, including but not limited to FDI stocks. Barkema and Vermeulen (1998) suggested that cultural differences increase the chance that a foreign joint venture will fail, while $\mathrm{Li}$ and Guisinger (1991) and Larimo (1998) found that cultural differences negatively impacted the survival of foreign subsidiaries.

Cultural differences can seriously affect decisions on FDI. Therefore, here, the impact of cultural differences between the source countries and Thailand on FDI stocks is first examined and then assessed. Previous studies pooled data from various host countries ( either one country, or many source countries), but we focus on and use data from Thailand. In other words, while other studies focused on the perspective of a source country, we consider this issue from the perspective of a host country. To study the effect of cultural distance, the data has been collected on stocks of FDIs held in Thailand by foreign entities from major source countries. Following the method of Kogut and Singh (1988), a cultural distance index between Thailand and each source country is constructed. The panel data covering 32 source countries has been collected for 2006-2019. The results of a random effects regression model indicate that cultural distance between Thailand and a source country is positively associated with the stock of FDI in Thailand.

The remainder of the paper is organized as follows. Section 1 presents literature review, Section 2 describes data collection and methodology, Section 3 presents the results while discussion and conclusion are drawn in the last section.

\section{Literature review}

The determinants of FDI in Thailand have been examined by a number of studies such 
Laoswatchaikul (2011), and Tanomponkang and Hovey (2014). They emphasized that Thailand had been depending heavily on FDI, especially from Japan and the United States. Most of the studies focused on variables from the gravity equation but none of them considered cultural variables.

The relationship between differences in national culture and FDI has been investigated by several studies. Some studies such as Dow and Ferencikova (2010) and Kandogan (2016) found negative effects of cultural differences on FDI, whereas others such as Voyer and Beamish (2004) and Peng and Beamish (2008) concluded that cultural differences did not affect FDI. Heavilin and Songur (2020) and Lucke and Eichler (2016) cited the positive effects of cultural differences on FDI.

To measure cultural differences, Kogut and Singh (1988) constructed a cultural distance index from Hofstede's (1980) cultural dimensions. According to Hofstede (2001), the cultural dimensions represent preferences for one state of affairs over another that distinguish countries, rather than individuals, from each other. In other words, they represent the collective programming of the mind that distinguishes the members of one group of people from others. Cultural distance, therefore, is defined as the extent to which the shared norms and values in one country differ from those in another (Drogendijk \& Slangen, 2006; Shenkar, 2001; Hofstede, 2001; Kogut \& Singh, 1988). In other words, the cultural distance is defined as the overall degree to which cultural values in one country are different from those in another country (Sousa \& Bradley, 2006).

Using Kogut and Singh's (1988) cultural distance index, Kandogan (2016) found a negative and significant relationship between cultural distance and FDI stock in bilateral data from 65 countries during the period 1990-2003. Similarly, Kang and Jiang (2012) found a negative and significant relationship between cultural distance and China's outward FDI stock in the 1996-2008 data. They argued that cultural distance was a major barrier for multinational enterprises in gaining normative legitimacy in host counties, and had a strong influence on FDI location choice.

In newer bilateral FDI data covering 29 source countries and 65 host countries from the period 1995-2009, Lucke and Eichler (2016) found a positive and significant relationship between cultural distance and FDI stock. Similarly, Heavilin and Songur (2020) found a positive and significant relationship between cultural distance and Turkey's outward FDI stock in the 2002-2016 data. On the other hand, Tomio and Amal (2015) found a positive but insignificant relationship between cultural distance and Brazil's outward FDI stock in the 2001-2013 data. Likewise, Zhang and Xu (2017) found a positive but insignificant relationship between cultural distance and China's outward FDI stock from the 2006-2014 data. They, however, found a positive and significant interaction effect of cultural distance and bilateral trade on China's outward FDI.

Overall, there are evidences for both negative and positive relationships between cultural distance and FDI. Interestingly, prior studies employing relatively old data tended to find a negative relationship, while recent studies using newer data tended to find a positive relationship. In addition, they either used data pooled from various home and host countries or used data from a single home or source country, but none of them used data from a single host country. In other words, they focused on the perspective of an investor or a source country, but not on the perspective of a host country. This study, therefore, use data from only one host country, namely Thailand, so as to consider the impact of cultural distance from the perspective of a host country. 


\section{Data and method}

Data on FDI in Thailand are obtained from the Bank of Thailand. Given the availability, we choose data covering 32 developing and developed source countries. They are listed in the Appendix. The panel data cover the period 2006-2019. The dependent variable is selected as FDI stock (SFDI) in Thailand from each source country. We choose FDI stocks rather than FDI flows because the stock variable is a more reliable measure. The stock variable is always non-negative while the flow is sometimes negative. The stock variable, therefore, gives a more persistent picture (Anderson, 2000). In addition, it provides a more accurate measure of FDI than the flow (Kang \& Jiang, 2012; Cezar \& Escobar, 2015).

Table 1 reports the stocks of FDI in Thailand from selected top ten source countries during the period 2015-2019. From Table 1, it can be noticed that the country with the highest stock of FDI in Thailand was Japan with a 2019 value of 92,381.31 million USD accounting for 34.48 percent of aggregate FDI stock in Thailand. It was followed by Singapore and Hong Kong whose 2019 FDI stocks in Thailand were 43,530.77 and 22,453.67 million USD, accounting for 16.25 and 8.38 percent, respectively. Throughout the whole period, the share of Japan's stock of FDI in Thailand remained the highest among all source countries. Interestingly, the United States which was ranked the third until 2016 has moved down to the fourth rank since 2017.

Table 1. Stocks of FDI in Thailand from major source countries, 2015-2019, millions of USD

\begin{tabular}{lrrrrr}
\hline Source country & 2015 & 2016 & 2017 & 2018 & 2019 \\
\hline Japan & $66,240.28$ & $72,402.48$ & $81,585.79$ & $86,810.11$ & $92,381.31$ \\
& $(35.07)$ & $(36.36)$ & $(35.27)$ & $(36.38)$ & $(34.49)$ \\
\hline Singapore & $27,393.46$ & $28,637.35$ & $34,716.31$ & $33,066.48$ & $43,530.77$ \\
& $(14.50)$ & $(14.38)$ & $(15.01)$ & $(13.86)$ & $(16.25)$ \\
\hline Hong Kong & $9,856.36$ & $11,571.77$ & $16,892.12$ & $17,821.74$ & $22,453.67$ \\
& $(5.22)$ & $(5.81)$ & $(7.30)$ & $(7.47)$ & $(8.38)$ \\
\hline The United States & $15,381.29$ & $15,011.41$ & $15,330.29$ & $16,233.67$ & $18,533.31$ \\
& $(8.14)$ & $(7.54)$ & $(6.63)$ & $(6.80)$ & $(6.92)$ \\
\hline Netherlands & $11,841.19$ & $11,293.01$ & $15,375.73$ & $15,646.42$ & $15,343.36$ \\
& $(6.27)$ & $(5.67)$ & $(6.65)$ & $(6.56)$ & $(5.73)$ \\
\hline The United Kingdom & $6,808.18$ & $6,734.80$ & $8,085.27$ & $8,143.33$ & $7,928.63$ \\
& $(3.60)$ & $(3.38)$ & $(3.50)$ & $(3.41)$ & $(2.96)$ \\
\hline China & $3,191.32$ & $4,556.06$ & $4,700.44$ & $5,532.20$ & $7,153.11$ \\
& $(1.69)$ & $(2.29)$ & $(2.03)$ & $(2.32)$ & $(2.67)$ \\
\hline Germany & $3,363.34$ & $3,647.13$ & $4,234.71$ & $4,441.48$ & $5,144.93$ \\
& $(1.78)$ & $(1.83)$ & $(1.83)$ & $(1.86)$ & $(1.92)$ \\
\hline South Korea & $2,877.99$ & $3,269.57$ & $3,442.70$ & $3,662.92$ & $4,121.72$ \\
& $(1.52)$ & $(1.64)$ & $(1.49)$ & $(1.54)$ & $(1.54)$ \\
\hline Switzerland & $3,390.70$ & $3,754.62$ & $3,802.34$ & $3,645.14$ & $4,023.33$ \\
& $(1.79)$ & $(1.89)$ & $(1.64)$ & $(1.53)$ & $(1.50)$ \\
\hline All countries & $188,905.58$ & $199,099.76$ & $231,316.53$ & $238,619.56$ & $267,866.00$ \\
\hline Note: The para
\end{tabular}

Note: The parentheses indicate percentages to aggregate FDI stock.

Source: Bank of Thailand

We include cultural distance, geographical distance, GDP, relative wage ratio, degree of trade openness, and exchange rate between each source country and Thailand as the main control variables. 
The cultural distance $(C D)$ is the difference in cultural scores between each source country and Thailand. Given its widespread use, we construct an index in the same manner as Kogut and Singh (1988). This method was adopted by numerous studies such as Heavilin and Songur (2020), Kandogan (2016), Kang and Jiang (2012), Lucke and Eichler (2016), Tomio and Amal (2015), and Zhang and Xu (2017). Specifically, the cultural distance is constructed from the average of the squared differences in cultural scores between each source country and Thailand. Each of the differences is corrected by its own variance. The index, therefore, is given by:

$$
C D_{i}=\frac{1}{N} \sum_{d=1}^{N} \frac{\left(S_{d, i}-S_{d, T H}\right)^{2}}{\sigma_{d}^{2}},
$$

where $S_{d, i}$ is the score of the cultural dimension $d$ of country $i, S_{d, T H}$ is such score of Thailand, and $\sigma_{d}^{2}$ is the cross-country variance of the score of the cultural dimension $d$. A high value for this index indicates a large cultural distance between the source country $i$ and Thailand. In other words, a high value for this means the source country $i$ and Thailand are more culturally distant. Similar to other studies, when computing the index, Hofstede's (1980, 2001), original cultural dimensions as power distance, individualism, uncertainty avoidance, and masculinity are used. They are constructed from survey responses of IBM employees collected between 1967 and 1973. They should still be representative because national culture is believed to change very slowly. Their definitions are reported in the Appendix.

To gain more insight, the original cultural distance $(C D)$ which is a composite measure will later be replaced with a single measure which uses only one cultural score. Specifically, the variables CDpdi, CDidv, CDmas, and CDuai are calculated from power distance, individualism, masculinity, and uncertainty avoidance, respectively.

The geographical distance (GDis) is the air distance between each source country's capital and Thailand's capital, Bangkok. This is included as a control for the transportation and transaction costs. Data on distance are obtained from the website 'distance.to'. Since a country from a greater distance tends to face more difficulty in investing abroad, the coefficient of GDis is expected to be negative.

The gross domestic product $(G D P)$ of each source country and that of Thailand (THGDP) are included as controls for the economic sizes of the source country and of Thailand. Data concerning GDP's are obtained from the World Bank. A high-income country tends to have more capability to invest abroad, thus, the coefficient of GDP is expected to be positive. Also, a high-income country tends to have a bigger market and be able to attract more foreign investors, thus, the coefficient of THGDP is expected to be positive.

The wage ratio (Wage) of each source country relative to Thailand is included as a control for differences in resource endowment and, thereby, the cost of production. Wage rates are computed from real GDP and labor force obtained from the World Bank. A country with a high wage rate tends to invest in a country with a lower wage rate to lower the cost of production, thus, the coefficient of Wage is expected to be positive.

The degree of trade openness (Open) between each source country and Thailand is included as a control for bilateral trade openness. The variable is computed by dividing the sum of export and import values between each source country and Thailand by Thailand's GDP. Export and import values are obtained from the United Nations Comtrade database, while Thailand's GDP is sourced from the World Bank. A country with a high trade volume with Thailand may face lower risk and uncertainty, thus, that country tends to invest more in Thailand. Therefore, the coefficient of Open is expected to be positive. Alternatively, trade and investment may substitute rather than complement each other. A source country may 
invest in Thailand to gain better access to the market and replace international trade. The coefficient of Open, therefore, may be expected to be negative. Thus, the coefficient of Open is expected to be either positive or negative.

The exchange rate $(X R)$ between each source country and Thailand is included as an additional control. The index is computed from the exchange rate measured as units of Thai Baht per unit of the source country's currency, with 2005 as the base year. Exchange rates are obtained from the Bank of Thailand. An appreciation of the source country's currency or an increase in the exchange rate may induce that country to invest more in Thailand, thus, the coefficient of $X R$ is expected to be positive.

To check the robustness of the results, the original cultural distance $(C D)$ which is calculated from four Hofstede's cultural dimensions will later be replaced with alternative measures. The variable $C D 5$ is constructed from five Hofstede's cultural dimensions including the original four dimensions and long-term orientation. The variable CD6 is constructed from six Hofstede's cultural dimensions including the original four dimensions, long-term orientation and indulgence. The last dimension was introduced in Hofstede, Hofstede, and Minkov (2010). The single measure variables CDlto and CDi are calculated from long-term orientation and indulgence, respectively.

Instead of Hofstede's cultural dimensions, the GLOBE cultural dimensions reported in House, Hanges, Javidan, Dorfman, and Gupta (2004) can be used to construct an alternative measure of cultural distance. The variable AltCD is constructed from nine GLOBE cultural dimensions, namely power distance, collectivism I, collectivism II, assertiveness, gender egalitarianism, uncertainty avoidance, future orientation, humane orientation, and performance orientation. They are constructed from survey responses of middle managers during the 1990s.

Table 2. Summary statistics

\begin{tabular}{lrrrrr}
\hline Variable & Mean & Standard Deviation & Minimum & Maximum & Observations \\
\hline $\ln S F D I$ & 6.290 & 2.403 & 0.113 & 11.434 & 448 \\
\hline CD & 1.723 & 1.059 & 0.242 & 3.558 & 32 \\
\hline $\ln$ GDis & 8.604 & 0.710 & 6.888 & 9.558 & 32 \\
\hline $\ln$ GDP & 27.292 & 1.286 & 24.471 & 30.693 & 446 \\
\hline $\ln$ THGDP & 26.633 & 0.257 & 26.125 & 27.022 & 14 \\
\hline Wage & 7.741 & 5.110 & 0.000 & 30.564 & 448 \\
\hline Open & 2.762 & 3.707 & 0.005 & 19.113 & 448 \\
\hline XR & 87.977 & 49.527 & 0.591 & 611.644 & 448 \\
\hline CDpdi & 1.112 & 1.190 & 0.002 & 4.972 & 32 \\
\hline CDidv & 2.808 & 2.759 & 0.000 & 8.678 & 32 \\
\hline CDmas & 1.845 & 2.086 & 0.011 & 10.550 & 32 \\
\hline CDuai & 1.129 & 1.287 & 0.002 & 6.124 & 32 \\
\hline CD5 & 1.748 & 0.926 & 0.343 & 3.865 & 32 \\
\hline CDlto & 1.844 & 2.197 & 0.002 & 8.719 & 32 \\
\hline CD6 & 1.631 & 0.851 & 0.299 & 3.227 & 32 \\
\hline CDi & 1.045 & 1.001 & 0.001 & 3.612 & 32 \\
\hline AltCD & 2.060 & 1.171 & 0.623 & 4.460 & 27 \\
\hline
\end{tabular}

The combined data set consists of 446 data points. The panel is slightly unbalanced because of missing data for Iran (period 2018-2019). Summary statistics are reported in Table 2. Interestingly, the variable $C D$ takes a minimum value of 0.242 for South Korea and a maximum value of 3.558 for the United Kingdom. Note that SFDI, GDis, GDP, and THGDP are included in their natural logarithm forms. There are no correlations between the main control variables exceeding 70 percent and, therefore, no multicollinearity problem. The list 
of source countries, the description of all variables, and the correlation matrix are reported in the Appendix.

We use a panel regression analysis to study the impact of cultural distance on FDI stock in Thailand. The regression model is given by:

$$
\begin{aligned}
\ln S F D I_{i t}= & \beta_{0}+\beta_{1} C D_{i}+\beta_{2} \ln \text { GDis }_{i}+\beta_{3} \ln G D P_{i t}+\beta_{4} \ln T H G D P_{i t} \\
& +\beta_{5} \text { Wage }_{i t}+\beta_{6} \text { Open }_{i t}+\beta_{7} X R_{i t}+\varepsilon_{i t},
\end{aligned}
$$

where $i$ represents source country and $t$ represents year. Note that cultural distance $(C D)$ and geographical distance (lnGDis) are time-invariant. Because some of the control variables are time-invariant and thus a fixed effects model cannot be used, we employ a random effects model to estimate the regression.

Table 3. Results of unit root tests

\begin{tabular}{lllrr}
\hline Variable & & W-statistic & p-value & Order of Integration \\
\hline $\ln S F D I$ & Level & $-2.714^{* * *}$ & 0.0033 & $\mathrm{I}(0)$ \\
\hline $\ln G D P$ & Level & $-4.876^{* * *}$ & 0.0000 & $\mathrm{I}(0)$ \\
\hline $\ln T H G D P$ & Level & $-5.372^{* * *}$ & 0.0000 & $\mathrm{I}(0)$ \\
\hline Wage & Level & $-5.707^{* * *}$ & 0.0000 & $\mathrm{I}(0)$ \\
\hline Open & Level & $-4.286^{* * *}$ & 0.0000 & $\mathrm{I}(0)$ \\
\hline$X R$ & Level & $-3.455^{* * *}$ & 0.0003 & $\mathrm{I}(0)$ \\
\hline
\end{tabular}

Note: The null hypothesis of the Im-Pesaran-Shin test is the presence of unit root. ***,**, and $*$ indicate significance at 1,5 , and 10 percent levels, respectively.

The control variables are tested for unit roots using the Im-Pesaran-Shin panel test. Results are reported in Table 3. All variables are stationary at level with a one percent significance level. Cultural distance $(C D)$ and geographical distance ( $\ln G D i s)$ are not tested because they are both time-invariant. All of the variables, therefore, enter the model in level.

\section{Results}

The results of the panel regression of $\ln S F D I$ are reported in Table 4. To overcome heteroskedasticity and autocorrelation problems, we employ robust standard errors when estimating the random effects model. All of the main control variables, $C D, \ln G D i s, \ln G D P$, $\ln T H G D P$, Wage, Open, and XR, enter the regression simultaneously.

The cultural distance $(C D)$ enters positively and significantly at the 1 percent level, suggesting that difference in culture is positively associated with FDI stock in Thailand. In other words, a culturally distant country tends to have more FDI in Thailand compared to a culturally close country. This finding contrasted with some previous studies using data pooled from various host countries. These typically indicated that difference in culture was negatively associated with FDI stock. Dow and Ferencikova (2010) and Kandogan (2016) also found that cultural differences were negatively associated with FDI. Our finding, however, concurs with Heavilin and Songur (2020) as well as Lucke and Eichler (2016) who stated that cultural distances were positively related to FDI.

Cultural distance shows a positive relationship, possibly because Thailand has succeeded in attracting FDI from other countries regardless of cultural differences. It may also be because Thai culture does not interfere with the operations of foreign companies but creates more opportunities. In other words, there are benefits to be gained by foreign companies investing in Thailand.

Table 4. Results of random effects estimation 


\begin{tabular}{|c|c|c|c|c|c|}
\hline & (1) & (2) & (3) & (4) & (5) \\
\hline$C D$ & $\begin{array}{l}1.142^{* * *} \\
(0.311)\end{array}$ & & & & \\
\hline $\ln G D i s$ & $\begin{array}{l}-1.192 \\
(0.763) \\
\end{array}$ & $\begin{array}{l}-0.493 \\
(0.689) \\
\end{array}$ & $\begin{array}{l}-1.403 \\
(1.025) \\
\end{array}$ & $\begin{array}{c}-0.463 \\
(0.710) \\
\end{array}$ & $\begin{array}{c}0.272 \\
(0.643) \\
\end{array}$ \\
\hline $\ln G D P$ & $\begin{array}{c}0.911^{* * * *} \\
(0.218)\end{array}$ & $\begin{array}{c}0.974^{* * * *} \\
(0.228)\end{array}$ & $\begin{array}{c}0.916^{* * * *} \\
(0.224)\end{array}$ & $\begin{array}{c}0.925^{* * *} \\
(0.225)\end{array}$ & $\begin{array}{c}0.942^{* * * *} \\
(0.214)\end{array}$ \\
\hline $\ln T H G D P$ & $\begin{array}{l}1.210^{* * * *} \\
(0.338)\end{array}$ & $\begin{array}{l}1.170^{* * * *} \\
(0.364)\end{array}$ & $\begin{array}{l}1.218^{* * * *} \\
(0.343)\end{array}$ & $\begin{array}{l}1.197^{* * * *} \\
(0.361)\end{array}$ & $\begin{array}{l}1.179^{* * * *} \\
(0.357)\end{array}$ \\
\hline Wage & $\begin{array}{c}-0.000470 \\
(0.0542)\end{array}$ & $\begin{array}{c}-0.00170 \\
(0.0603)\end{array}$ & $\begin{array}{l}0.00207 \\
(0.0571) \\
\end{array}$ & $\begin{array}{c}-0.00148 \\
(0.0600)\end{array}$ & $\begin{array}{r}-0.00465 \\
(0.0588)\end{array}$ \\
\hline Open & $\begin{array}{c}0.0138 \\
(0.0258) \\
\end{array}$ & $\begin{array}{c}0.0172 \\
(0.0257) \\
\end{array}$ & $\begin{array}{c}0.0184 \\
(0.0252) \\
\end{array}$ & $\begin{array}{c}0.0136 \\
(0.0266) \\
\end{array}$ & $\begin{array}{c}0.0168 \\
(0.0254) \\
\end{array}$ \\
\hline$X R$ & $\begin{array}{l}-0.00123 \\
(0.00145)\end{array}$ & $\begin{array}{c}-0.00133 \\
(0.00149)\end{array}$ & $\begin{array}{c}-0.00127 \\
(0.00144)\end{array}$ & $\begin{array}{c}-0.00130 \\
(0.00147)\end{array}$ & $\begin{array}{l}-0.00129 \\
(0.00148)\end{array}$ \\
\hline CDpdi & & $\begin{array}{c}0.271 \\
(0.246) \\
\end{array}$ & & & \\
\hline$C D i d v$ & & & $\begin{array}{l}0.378^{* *} \\
(0.167)\end{array}$ & & \\
\hline CDmas & & & & $\begin{array}{l}0.260^{* * *} \\
(0.108)\end{array}$ & \\
\hline CDuai & & & & & $\begin{array}{c}0.756^{* * *} \\
(0.239)\end{array}$ \\
\hline Constant & $\begin{array}{c}-42.42^{* * *} \\
(8.764) \\
\end{array}$ & $\begin{array}{c}-47.41^{* * *} \\
(8.414) \\
\end{array}$ & $\begin{array}{c}-40.11^{* * *} \\
(10.58)\end{array}$ & $\begin{array}{c}-47.24^{* * *} \\
(8.559) \\
\end{array}$ & $\begin{array}{c}-53.93^{* * * *} \\
(7.905) \\
\end{array}$ \\
\hline R-squared (within) & 0.640 & 0.641 & 0.640 & 0.640 & 0.641 \\
\hline R-squared (between) & 0.445 & 0.263 & 0.350 & 0.301 & 0.378 \\
\hline R-squared (overall) & 0.452 & 0.282 & 0.363 & 0.318 & 0.391 \\
\hline Wald chi-square & 399.4 & 316.7 & 312.3 & 322.1 & 404.5 \\
\hline p-value & 0.0000 & 0.0000 & 0.0000 & 0.0000 & 0.0000 \\
\hline Observations & 446 & 446 & 446 & 446 & 446 \\
\hline Countries & 32 & 32 & 32 & 32 & 32 \\
\hline
\end{tabular}

Note: The errors are clustered at the country level. Robust clustered standard errors are reported in parentheses. $* * *, * *$, and $*$ indicate significance at 1,5 , and 10 percent levels, respectively.

When a measure of cultural distance is changed from a composite measure, $C D$, to a single measure, namely CDpdi, CDidv, CDmas, and CDuai, all of them enter positively but only the last three measures enter significantly at 5, 5, and 1 percent level, respectively. Thailand scores low on individualism and masculinity at 20 and 34, respectively. On the other hand, Thailand scores relatively high on uncertainty avoidance at 64 . This means that Thai culture is relatively on the collective and feminine sides, and tends to avoid the uncertainty. These characteristics may be attracting foreign investors with different culture rather than repelling them.

The gross domestic product $(\ln G D P)$ of the source country and the gross domestic product of Thailand $(\ln T H G D P)$ enter positively and significantly at the 1 percent level. This means that the economic sizes of the source country and Thailand are positively associated with FDI stock in Thailand. This finding is consistent with the gravity model of FDI. A highincome country tends to have more FDI stock in Thailand than a low-income nation. This result concurs with Anuchitworawong and Thampanishvong (2015), Daly and Tosompark (2011), and Laoswatchaikul (2011). 
The geographical distance $(\ln G D i s)$, the relative wage ratio (Wage), the degree of trade openness (Open), and the exchange rate $(X R)$ do not enter significantly. Thus, there is no evidence that the geographical distance, the relative wage ratio, the bilateral trade openness, and the exchange rate between the source country and Thailand are associated with FDI stock in Thailand.

To check the robustness of the results, the original cultural distance $(C D)$ is replaced with alternative measures of cultural distance, namely CD5, CDlto, CD6, CDi, and AltCD. The results are reported in Table 5. All of them enter positively but only the composite measures enter significantly (at 1 percent level). The positive relationship between cultural distance and FDI stock in Thailand, therefore, is robust to a change in measure of cultural distance.

Table 5. Results of random effects estimation - alternative cultural distance measures

\begin{tabular}{|c|c|c|c|c|c|}
\hline & (6) & (7) & $(8)$ & (9) & (10) \\
\hline CD5 & $\begin{array}{l}1.410^{* * * *} \\
(0.352)\end{array}$ & & & & \\
\hline CDlto & & $\begin{array}{l}0.207 \\
(0.145)\end{array}$ & & & \\
\hline CD6 & & & $\begin{array}{l}1.512^{* * *} \\
(0.398)\end{array}$ & & \\
\hline$C D i$ & & & & $\begin{array}{l}0.415 \\
(0.354)\end{array}$ & \\
\hline AltCD & & & & & $\begin{array}{l}0.943^{* * *} \\
(0.197) \\
\end{array}$ \\
\hline $\ln G D i s$ & $\begin{array}{l}-1.106 \\
(0.703)\end{array}$ & $\begin{array}{l}-0.287 \\
(0.703) \\
\end{array}$ & $\begin{array}{l}-1.128 \\
(0.716) \\
\end{array}$ & $\begin{array}{l}-0.519 \\
(0.712) \\
\end{array}$ & $\begin{array}{l}-1.528^{* * *} \\
(0.358)\end{array}$ \\
\hline $\ln G D P$ & $\begin{array}{l}0.839^{* * * *} \\
(0.224)\end{array}$ & $\begin{array}{l}0.912^{* * * *} \\
(0.229)\end{array}$ & $\begin{array}{l}0.843^{* * *} \\
(0.223) \\
\end{array}$ & $\begin{array}{l}0.940^{* * *} \\
(0.220)\end{array}$ & $\begin{array}{l}0.861^{* * *} \\
(0.202)\end{array}$ \\
\hline $\ln T H G D P$ & $\begin{array}{l}1.270^{* * * *} \\
(0.350)\end{array}$ & $\begin{array}{l}1.214^{* * * *} \\
(0.368)\end{array}$ & $\begin{array}{l}1.276^{* * * *} \\
(0.350)\end{array}$ & $\begin{array}{l}1.209^{* * * *} \\
(0.358)\end{array}$ & $\begin{array}{l}1.382^{* * * *} \\
(0.384)\end{array}$ \\
\hline Wage & $\begin{array}{l}0.00527 \\
(0.0570)\end{array}$ & $\begin{array}{l}0.000675 \\
(0.0626)\end{array}$ & $\begin{array}{l}0.00733 \\
(0.0569)\end{array}$ & $\begin{array}{l}0.00388 \\
(0.0602)\end{array}$ & $\begin{array}{l}0.0870 \\
(0.0620)\end{array}$ \\
\hline Open & $\begin{array}{l}0.0129 \\
(0.0255)\end{array}$ & $\begin{array}{l}0.0162 \\
(0.0259)\end{array}$ & $\begin{array}{l}0.0136 \\
(0.0256)\end{array}$ & $\begin{array}{l}0.0180 \\
(0.0255)\end{array}$ & $\begin{array}{l}0.0208 \\
(0.0276)\end{array}$ \\
\hline$X R$ & $\begin{array}{l}-0.00120 \\
(0.00140)\end{array}$ & $\begin{array}{l}-0.00131 \\
(0.00145)\end{array}$ & $\begin{array}{l}-0.00120 \\
(0.00139)\end{array}$ & $\begin{array}{l}-0.00132 \\
(0.00145)\end{array}$ & $\begin{array}{l}-0.00156 \\
(0.00148)\end{array}$ \\
\hline Constant & $\begin{array}{l}-43.38^{* * * *} \\
(8.719)\end{array}$ & $\begin{array}{l}-48.78^{* * * *} \\
(8.683)\end{array}$ & $\begin{array}{l}-43.44^{* * * *} \\
(8.744)\end{array}$ & $\begin{array}{l}-47.50^{* * * *} \\
(8.622)\end{array}$ & $\begin{array}{l}-43.11^{* * * *} \\
(6.638)\end{array}$ \\
\hline R-squared (within) & 0.638 & 0.640 & 0.638 & 0.639 & 0.608 \\
\hline R-squared (between) & 0.512 & 0.292 & 0.505 & 0.287 & 0.755 \\
\hline R-squared (overall) & 0.514 & 0.311 & 0.507 & 0.305 & 0.741 \\
\hline Wald chi-square & 539.3 & 415.6 & 542.8 & 355.4 & 336.8 \\
\hline p-value & 0.0000 & 0.0000 & 0.0000 & 0.0000 & 0.0000 \\
\hline Observations & 446 & 446 & 446 & 446 & 376 \\
\hline Countries & 32 & 32 & 32 & 32 & 27 \\
\hline
\end{tabular}

Note: The errors are clustered at the country level. Robust clustered standard errors are reported in parentheses. $* * *, * *$, and $*$ indicate significance at 1,5 , and 10 percent levels, respectively.

To sum up, the regression results indicate that FDI stock in Thailand is positively associated with cultural distance and gross domestic products of the source country and Thailand. The results are also robust to different measures of cultural distance. 


\section{Discussion and conclusions}

This paper examines the effect of cultural distance on FDI stock in Thailand. Most previous studies used data from various host countries but here we only focus on and use data from one host country, Thailand. Using the method developed by Kogut and Singh (1988), the cultural distance index between Thailand and each source country is constructed and used. Similar to other studies, data on culture are obtained from Hofstede (1980, 2001), Hofstede et al. (2010) and the GLOBE project (House et al., 2004). Panel data covering 32 developing and developed home or source countries are collected from 2006-2019.

Results from a random effects regression model indicate that cultural distance between Thailand and its source country is positively associated with stock of FDI in Thailand. In other words, a country with a diverse culture from Thailand tends to have a higher FDI stock in Thailand compared to a country with a similar culture. This finding is in contrast with Kandogan (2016), which found a negative relationship between cultural distance and FDI stock in the 1990-2003 data covering 65 countries. This finding, however, is consistent with Heavilin and Songur (2020), which found that cultural distance is positive related to Turkey's outward FDI stock during the period 2002-2016, as well as Lucke and Eichler (2016), which found a positive relationship between cultural distance and FDI stock in the 1995-2009 data covering 29 source countries and 65 host countries. Interestingly, we can notice that this finding is in contrast with prior studies employing relatively old data but is consistent with recent studies using newer data. This possibly indicates that cultural differences are no longer challenge for international business operations.

This finding of a positive relationship cultural distance and FDI stock in Thailand contributes to the body of literature on culture and FDI. It provides another evidence for the positive association between cultural differences and FDI as found by some recent studies. It is important to note that, while those studies use data pooled from various source countries and host countries or data from only one source country, we use data from a single host country, namely Thailand. This means that the positive relationship holds even when it is viewed from the perspective of a host country.

Considering the finding of such positive relationship, we conclude that Thai culture does not obstruct the operations of foreign firms but creates greater opportunities, with increased benefits for foreign companies to conduct business in Thailand. Thai culture does not hinder or obstruct the operations of foreign firms possibly because it is collective and feminine, and tends to avoid the uncertainty. There may be more opportunities and benefits for foreign companies to invest in Thailand possibly because Thai consumers tend to prefer foreign products with high qualities and known brand names. This, together with Thailand's large domestic market and skilled labor force, makes foreign investment fruitful. Furthermore, Thailand is strategically located at the hub of ASEAN countries, and the country has good infrastructure and world-class industrial estates that are attractive for foreign firms (Huang, Ruangkanjanases, \& Chen, 2014). Furthermore, when a firm from an individualistic culture invests in a collectivist country, like Thailand, there is less acculturative stress but more entrepreneurial activities. Moreover, there is less acculturative stress in a high uncertainty avoidance country, like Thailand, because the hierarchy of the organizational structure is consistent with parents' and subsidiaries' value towards rule and uncertainty avoidance (Tang, 2012).

The Thai Government can promote FDI by highlighting the benefits of foreign business investment in Thailand, especially for firms from countries with diverse cultures from Thailand. Specifically, the government should aim at source countries with individualistic, masculine, and low uncertainty avoidance culture. In promoting and attracting FDI into Thailand, the government should emphasize that Thai culture is collective, feminine, 
and high uncertainty avoidance. The government may even highlight that there is less acculturative stress in Thailand.

\section{Acknowledgement}

The authors would like to thank Manachaya Uruyos, Patrik Zoltan Karpaty, Rosada Vesdapunt, Scott Orr, Woradee Jongadsayakul, and participants at the 94th WEAI Annual Conference for their helpful comments and suggestions. We also would like to thank the Editor and anonymous reviewers for their helpful and constructive comments. We also gratefully acknowledge the research grant (18/2561) from the Department of Economics at Kasetsart University.

\section{References}

Ananchotikul, N. (2008). Does Foreign Direct Investment Really Improve Corporate Governance? Evidence from Thailand (Monetary Policy Group, Bank of Thailand Working Paper No. 2008-09).

Anderson, J. E. (2000). Why do nations trade (so little)? Pacific Economic Review, 5, 115134.

Anuchitworawong, C., \& Thampanishvong, K. (2015). Determinants of foreign direct investment in Thailand: Does natural disaster matter? International Journal of Disaster Risk Reduction, 14(3), 312-321.

Barkema, H. G., \& Vermeulen, F. (1998). International expansion through start up or acquisition: A learning perspective. The Academy of Management Journal, 41(1), 726.

Blonigen, B. A., \& Piger, J. (2014). Determinants of foreign direct investment. Canadian Journal of Economics, (3)47, .81-775

Cezar, R., \& Escobar, O. R. (2015). Institutional distance and foreign direct investment. Review World Economics, 151(4), 713-733.

Constanza, B. (2001). The effect of cultural differences on service encounter satisfaction. Proceedings of 2001 AMA Winter Educators' Conference (pp. 46-52). Chicago, IL: American Marketing Association.

Daly, K., \& Tosompark, C. T. (2011). Determinants of foreign direct investment in Thailand. In J. A. Battern \& P. G. Szilagyi (Eds.), The Impact of the Global Financial Crisis on Emerging Financial Markets (pp.709 - 718). UK: Emerald.

Dow, D., \& Ferencikova, S. ( .(2010More than just national cultural distance: Testing new distance scales on FDI in Slovakia. International Business Review, (1)19, .58-46

Drogendijk, R., \& Slangen, A. (2006). Hofstede, Schwartz, or managerial perceptions? The effects of different cultural distance measures on establishment mode choices by multinational enterprises. International Business Review, 15(4), 361-380.

Gomez-Mejia, L., \& Palich, L. (1997). Cultural diversity and the performance of multinational frms. Journal of International Business Studies, 28(2), 309-335.

Hakanson, L., \& Ambos, B. (2010). The antecedents of psychic distance. Journal of International Management, 16(3), 195-210.

Heavilin, J., \& Songur, H. (2020). Institutional distance and Turkey's outward foreign direct investment. Research in International Business and Finance, 54, 1-16.

Hofstede, G. (1980). Culture's Consequences: International Differences in Work-Related Values. Thousand Oaks, CA: Sage. 
Hofstede, G. (2001). Culture's consequences: Comparing values, behaviors, institutions, and organizations across nations. Thousand Oaks, CA: Sage.

Hofstede, G., Hofstede, G. J., \& Minkov, M. (2010). Cultures and organizations: Software of the mind ( $3^{\text {rd }}$ ed.). New York: McGraw-Hill.

House, R. J., Hanges, P. J., Javidan, M., Dorfman, P.W., \& Gupta, V. (2004). Culture, Leadership, and Organizations: The GLOBE Study of 62 Societies. Thousand Oaks: Sage.

Huang, X. L., Ruangkanjanases, A. \& Chen, C. (2014). Factors influencing Chinese firms' decision making in foreign direct investment in Thailand. International Journal of Trade, Economics and Finance, 5(6), 463-471.

Kandogan, Y. (2016). Economic development, cultural differences and FDI, Applied Economics, 48(17), 1545-1559.

Kang, Y., \& Jiang, F. (2012). FDI location choice of Chinese multinationals in East and Southeast Asia: Traditional economic factors and institutional perspective. Journal of World Business, 47(1), 45-53.

Kogut, B., \& Singh, H. (1988). The effect of national culture on the choice of entry mode. Journal of International Business Studies, 19, 411-432.

Kohpaiboon, A. (2006). Foreign direct investment and technology spillover: A cross-industry analysis of Thai manufacturing. World Development, 34(3), 541-556.

Laoswatchaikul (2011). The determinants and impacts of foreign direct investment in the Thai manufacturing sector: A three-way fixed effects approach (Doctoral dissertation). University of Missouri-Columbia.

Larimo, J. (1998). Determinants of Divestments in Foreign Production Operations Made by Finnish Firms in OECD Countries (University of Vaasa, Finland, Discussion Paper No. 223).

Li, J., \& Guisinger, S. (1991). Comparative business failures of foreign-controlled firms in the United States. Journal of International Business Studies, 22(2), 209-224.

Lucke, N., \& Eichler, S. ( .(2016Foreign direct investment: the role of institutional and cultural determinants. Applied Economics, (11)48, .956-935

Nayak, B. S., \& Scheib, D. (2020). Cultural logic of German foreign direct investment (FDI) in service sector, Journal of Economic Structures, 9(1), 1-13.

Peng, G. Z., \& Beamish, P. W. (2008). The effect of national corporate responsibility environment on Japanese foreign direct investment. Journal of Business Ethics, 80(4), 677-695.

Shenkar, O. (2001). Cultural distance revisited: Towards a more rigorous conceptualization and measurement of cultural differences. Journal of International Business Studies, $32,519-535$.

Sousa, C. M. P., \& Bradley, F. (2006). Cultural Distance and Psychic Distance: Two Peas in a Pod? Journal of International Marketing, 14(1), 49-70.

Su, D. T., Nguyen, P. C., \& Christophe, S. (2019). Impact of foreign direct investment, trade openness and economic institutions on growth in emerging countries: The case of Vietnam. Journal of International Studies, 12(3), 243-264.

Tahir, R., \& Larimo, J. (2004). Understanding the location strategies of the European firms in Asian countries. Journal of American Academy of Business, 5(1/2), 102-109.

Tang, L. (2012). The direction of cultural distance on FDI: attractiveness or incongruity? Cross Cultural Management, 19(2), 233-256.

Tanomponkang, K., \& Hovey, M. (2014). Foreign direct investment and emerging markets: A study of direct investment in Thailand with a focus on Australia investment, Proceedings of International Conference on Trends in Economics, Humanities and Management (ICTEHM'14) (pp. 23-32). 
Tomio, B. T., \& Amal, M., (2015). Institutional distance and Brazilian outward foreign direct investment. Management, 18(1), 78-101.

Vasa, L., \& Angeloska, A. (2020). Foreign direct investment in the Republic of Serbia: Correlation between foreign direct investments and the selected economic variables. Journal of International Studies, 13(1), 170-183

Voyer, P. A., \& Beamish, P. W. ( .(2004The effect of corruption on Japanese foreign direct investment. Journal of Business Ethics, (3)50, .224-211

Yusoff, M. B., \& Nuh, R. (2015). Foreign direct investment, trade openness and economic growth: Empirical evidence from Thailand. Foreign Trade Review, 50(2), 73-84.

Zhang, L., \& Xu, Z. (2017). How do cultural and institutional distance affect China's OFDI towards the OBOR countries? Baltic Journal of European Studies, 7(1), 24-42. 


\section{Appendix}

The data set includes 32 home or source countries, namely Indonesia, Malaysia, The Philippines, Singapore, Vietnam, Austria, Belgium, Denmark, Finland, France, Germany, Ireland, Italy, Luxembourg, Netherlands, Spain, Sweden, The United Kingdom, Iran, Kuwait, Saudi Arabia, United Arab Emirates, Australia, China, Hong Kong, India, Japan, New Zealand, Russia, South Korea, Switzerland, and The United States.

Table A1. Description of variables

\begin{tabular}{|c|c|c|}
\hline Variable & Description & Source \\
\hline $\ln S F D I$ & FDI stock in Thailand from each source country. & $\begin{array}{l}\text { Bank of } \\
\text { Thailand }\end{array}$ \\
\hline$C D$ & $\begin{array}{l}\text { Difference in cultural scores between Thailand and each source country. } \\
\text { This measure is computed from four Hofstede's cultural dimensions, } \\
\text { namely power distance, individualism, masculinity, and uncertainty } \\
\text { avoidance. }\end{array}$ & $\begin{array}{l}\text { Hofstede } \\
\text { Insights }\end{array}$ \\
\hline $\ln G D i s$ & $\begin{array}{l}\text { Air distance between the capital of Thailand (Bangkok) and the capital } \\
\text { of each source country. }\end{array}$ & Distance.to \\
\hline $\ln G D P$ & Nominal gross domestic product of each source country. & World Bank \\
\hline $\ln T H G D P$ & Nominal gross domestic product of Thailand. & World Bank \\
\hline Wage & $\begin{array}{l}\text { Ratio of each source country's average wage relative to Thailand's } \\
\text { average wage. The average wage rate is calculated from real GDP and } \\
\text { labor force. }\end{array}$ & World Bank \\
\hline Open & $\begin{array}{l}\text { Degree of trade openness between each source country and Thailand. } \\
\text { The sum of export and import values is divided by the nominal gross } \\
\text { domestic product of Thailand. }\end{array}$ & $\begin{array}{l}\text { UN Comtrade } \\
\text { and World } \\
\text { Bank }\end{array}$ \\
\hline$\overline{X R}$ & $\begin{array}{l}\text { Exchange rate index between each source country and Thailand. This } \\
\text { index is computed from the exchange rate measured as units of Thai } \\
\text { Baht per unit of the source country's currency, with } 2005 \text { as the base } \\
\text { year. }\end{array}$ & $\begin{array}{l}\text { Bank of } \\
\text { Thailand }\end{array}$ \\
\hline CDpdi & $\begin{array}{l}\text { Difference in Hofstede's power distance score between Thailand and } \\
\text { each source country. Power distance is defined as the extent to which } \\
\text { the less powerful members of institutions and organisations within a } \\
\text { country expect and accept that power is distributed unequally. }\end{array}$ & $\begin{array}{l}\text { Hofstede } \\
\text { Insights }\end{array}$ \\
\hline$C D i d v$ & $\begin{array}{l}\text { Difference in Hofstede's individualism score between Thailand and } \\
\text { each source country. This dimension describes the degree of } \\
\text { interdependence a society maintains among its members. }\end{array}$ & $\begin{array}{l}\text { Hofstede } \\
\text { Insights }\end{array}$ \\
\hline CDmas & $\begin{array}{l}\text { Difference in Hofstede's masculinity score between Thailand and each } \\
\text { source country. A high score on this dimension indicates that the society } \\
\text { will be driven by competition, achievement and success, with success } \\
\text { being defined by the "winner" or "best-in-the-field". }\end{array}$ & $\begin{array}{l}\text { Hofstede } \\
\text { Insights }\end{array}$ \\
\hline CDuai & $\begin{array}{l}\text { Difference in Hofstede's uncertainty avoidance score between Thailand } \\
\text { and each source country. Uncertainty avoidance is defined as the extent } \\
\text { to which the members of a culture feel threatened by ambiguous or } \\
\text { unknown situations and have created beliefs and institutions that try to } \\
\text { avoid these. }\end{array}$ & $\begin{array}{l}\text { Hofstede } \\
\text { Insights }\end{array}$ \\
\hline CD5 & $\begin{array}{l}\text { Difference in cultural scores between Thailand and each source country. } \\
\text { This measure is computed from five Hofstede's cultural dimensions, } \\
\text { namely power distance, individualism, masculinity, uncertainty } \\
\text { avoidance, and long-term orientation. }\end{array}$ & $\begin{array}{l}\text { Hofstede } \\
\text { Insights }\end{array}$ \\
\hline
\end{tabular}




\begin{tabular}{lll}
\hline Variable & Description & Source \\
\hline CDlto & $\begin{array}{l}\text { Difference in Hofstede's long-term orientation score between Thailand } \\
\text { and each source country. This dimension describes how every society } \\
\text { has to maintain some links with its own past while dealing with the } \\
\text { challenges of the present and future. }\end{array}$ & $\begin{array}{l}\text { Hofstede } \\
\text { Insights }\end{array}$ \\
\hline CD6 & $\begin{array}{l}\text { Difference in cultural scores between Thailand and each source country. } \\
\text { This measure is computed from six Hofstede's cultural dimensions, } \\
\text { namely power distance, individualism, masculinity, uncertainty } \\
\text { avoidance, long-term orientation, and indulgence. }\end{array}$ & Hofstede \\
& Insights \\
\hline$C D i$ & $\begin{array}{l}\text { Difference in Hofstede's indulgence score between Thailand and each } \\
\text { source country. This dimension describes the extent to which people try } \\
\text { to control their desires and impulses. }\end{array}$ & Insights \\
\hline AltCD & $\begin{array}{l}\text { Difference in cultural scores between Thailand and each source country. } \\
\text { This measure is computed from nine GLOBE cultural dimensions, }\end{array}$ & GLOBE \\
& $\begin{array}{l}\text { namely power distance, collectivism I, collectivism II, assertiveness, } \\
\text { gender egalitarianism, uncertainty avoidance, future orientation, humane } \\
\text { orientation, and performance orientation. }\end{array}$ & \\
& & \\
\hline
\end{tabular}


RECENT ISSUES IN ECONOMIC DEVELOPMENT

Table A2. Correlation matrix of control variables

\begin{tabular}{|c|c|c|c|c|c|c|c|}
\hline & $C D$ & $\ln G D i s$ & $\ln G D P$ & Wage & Open & $X R$ & CDpdi \\
\hline $\ln G D i s$ & $0.5027 *$ & 1 & & & & & \\
\hline $\ln G D P$ & $0.2847 *$ & $0.2670 *$ & 1 & & & & \\
\hline Wage & $0.4764 *$ & $0.5959 *$ & $-0.1791^{*}$ & 1 & & & \\
\hline Open & $0.1274 *$ & $-0.2845^{*}$ & $0.5464 *$ & $-0.1923^{*}$ & 1 & & \\
\hline$X R$ & -0.0975 & 0.0925 & 0.006 & -0.0415 & -0.0243 & 1 & \\
\hline CDpdi & $0.5690 *$ & $0.3042 *$ & $-0.2289 *$ & $0.2455^{*}$ & $-0.2575^{*}$ & -0.0645 & 1 \\
\hline$C D i d v$ & $0.7512 *$ & $0.7208 *$ & 0.2978* & $0.5161 *$ & $-0.1476^{*}$ & -0.0541 & $0.2982 *$ \\
\hline CDmas & $0.6270^{*}$ & $0.1638^{*}$ & $0.3443 *$ & 0.1918* & $0.4768 *$ & -0.016 & $0.2274 *$ \\
\hline CDuai & $0.1384 *$ & $-0.4379 *$ & -0.0508 & -0.0764 & $0.2009 *$ & -0.1192 & -0.0599 \\
\hline CD5 & $0.8808 *$ & $0.4235^{*}$ & $0.4432 *$ & $0.4200 *$ & $0.2966^{*}$ & -0.1125 & $0.3813^{*}$ \\
\hline CDlto & -0.0726 & -0.0771 & $0.3823^{*}$ & -0.0337 & $0.3792 *$ & -0.049 & $-0.2939^{*}$ \\
\hline CD6 & $0.8953 *$ & $0.4363 *$ & $0.4150 *$ & $0.4096 *$ & $0.2569 *$ & $-0.1247 *$ & $0.4254 *$ \\
\hline$C D i$ & $0.4956^{*}$ & $0.2683^{*}$ & 0.0675 & $0.1480 *$ & -0.0605 & -0.1161 & $0.4078 *$ \\
\hline AltCD & $0.3870^{*}$ & $0.1687^{*}$ & -0.1246 & $0.5853^{*}$ & -0.1046 & -0.1038 & $0.3470 *$ \\
\hline & $C D i d v$ & CDmas & CDuai & CD5 & CDlto & CD6 & $C D i$ \\
\hline CDmas & $0.1409 *$ & 1 & & & & & \\
\hline CDuai & $-0.1757 *$ & -0.0692 & 1 & & & & \\
\hline CD5 & $0.5758 *$ & $0.6856^{*}$ & $0.2010^{*}$ & 1 & & & \\
\hline CDlto & $-0.2355^{*}$ & $0.2352 *$ & $0.1564 *$ & $0.4082 *$ & 1 & & \\
\hline CD6 & $0.6164 *$ & $0.6299 *$ & $0.2108 *$ & $0.9837^{*}$ & $0.3460 *$ & 1 & \\
\hline$C D i$ & $0.4832 *$ & 0.0441 & $0.1466^{*}$ & $0.3957 *$ & $-0.1220 *$ & $0.5545^{*}$ & 1 \\
\hline Alt $C D$ & $0.2395^{*}$ & 0.0233 & $0.3656^{*}$ & $0.4732 *$ & $0.2034 *$ & $0.4943 *$ & $0.3086 *$ \\
\hline
\end{tabular}

Note: Correlation coefficients greater than 0.7 or smaller than -0.7 are typed in italics. * indicates significance at 1percent level. 